Staniseawa Kalus, ${ }^{1}$ Magdalena Habdas ${ }^{2}$

\title{
Ustawa o planowaniu i zagospodarowaniu przestrzennym jako instrument kształtowania wartości rynkowej nieruchomości
}

\section{Wstęp}

Stwierdzenie, że nieruchomości są niezwykle istotnym elementem rynku w gospodarce rynkowej, jest obecnie aksjomatem. Przemiany gospodarki polskiej polegające na odejściu od zasad gospodarki nakazowo-rozdzielczej na rzecz gospodarki rynkowej, jakie miały miejsce od końca 1989 roku, znalazły swój wyraz najdobitniej właśnie w kształtowaniu zasobów podlegających obrotowi rynkowemu nieruchomości, wprowadzenia wskutek prywatyzacji przedsiębiorstw państwowych, a potem wprowadzenia własności samorządowej i objęciem przez gminy znacznego zasobu nieruchomości, często kierowanych do obrotu powszechnego, wdrożenia zasad gospodarowania nieruchomościami, a przede wszystkim wprowadzenia różnych rodzajów wartości nieruchomości i zasad ich określania.

Rynek nieruchomości pojmowany jest przez część doktryny jako „ogół warunków, w których odbywa się transfer praw do nieruchomości i są zawierane umowy stwarzające wzajemne prawa i obowiązki, połączone $\mathrm{z}$ władaniem nieruchomościami". ${ }^{3}$ Jest on jednak bardziej skomplikowany co do swej istoty, w związku z czym używana jest także definicja M. Bryxa, wedle którego w pojęciu tym należy uwzględniać nie tylko transakcje sprzedaży, ale także:

- umowy dotyczące powstania i przeniesienia innych praw rzeczowych do nieruchomości, nie tylko prawa własności,

- inwestycje rzeczowe w nieruchomości, skutkujące wzrostem użyteczności lub wartości oraz transakcje dokonywane $\mathrm{w}$ trakcie inwestowania i po zakończeniu inwestycji,

Por. E. Kucharska-Stasiak, Nieruchomość a rynek, Warszawa 1997, s. 25. 
Ustawa o planowaniu i zagospodarowaniu przestrzennym jako instrument...

- przeciwdziałanie utracie lub zmniejszeniu wartości nieruchomości, zarządzanie nimi poprzez remonty, modernizacje, adaptacje, rozbudowę,

- umowy dotyczące innych usług sprzyjających lepszemu wykorzystaniu nieruchomości,

- wiążące się ze specjalnymi instrumentami finansowymi, przepływami wyodrębnionych środków pieniężnych, zasilających nieruchomości i działania w stosunku do nich. ${ }^{4}$

Definicje te, jako wypracowane przez ekonomistów, wykazują jednak pewną ułomność. Transakcje dotyczące nieruchomości występowały bowiem także na gruncie gospodarki nakazowo-rozdzielczej, gdyż nigdy nie zniesiono w Polsce prywatnej własności nieruchomości, jednakże nie sposób twierdzić, że istniał wówczas rynek nieruchomości. Do tego bowiem, aby on zaistniał konieczne jest oparcie systemu zawierania umów dotyczących nieruchomości na zasadzie autonomii woli stron i kształtowanie ich przy uwzględnieniu swobody stron co do kształtowania ich treści, zwłaszcza co do cen tego towaru, jakim są nieruchomości, byleby treść tych umów lub ich cel nie sprzeciwiały się właściwości (naturze) stosunku, ustawie ani zasadom współżycia społecznego (art. $353^{1} \mathrm{kc}$.). ${ }^{5}$

Jak istotny jest ten element definicji rynku, będzie mowa także poniżej, przy analizie pojęcia wartości rynkowej nieruchomości.

Nieruchomości, jako towar na rynku, mają szereg istotnych cech wpływających na ich wartość, a poprzez to na cenę, jaką za nie można uzyskać w obrocie. Większość tych cech ma związek z planowaniem i zagospodarowaniem przestrzennym, co staramy się także poniżej wykazać. Są to zarówno cechy fizyczne, jak: złożoność fizyczna, stałość w miejscu, trwałość, różnorodność czy niepodzielność fizyczna. Wyodrębnia się także cechy instytucjonalne nieruchomości, jak: rozmaitość praw do nieruchomości odnosząca się do ich charakteru (prawa bezwzględne czy względne), rejestrów publicznych, które je obejmują (kataster i księgi wieczyste), czy wreszcie do określania zasad gospodarowania niektórymi z nich (nieruchomości zasobowe), a ponadto zwraca się uwagę na to, że nieruchomości stanowią przedmiot badań, analizy oraz zainteresowań nauki. ${ }^{6}$

$4 \quad$ Ibidem.

5 Por. M. Safjan, (w:) Kodeks cywilny. Komentarz t. I, pod red. K.Pietrzykowskiego, Warszawa 2000, s. 724 i nast.; Cz. Żuławska, Wokół zasady wolności umów - art. $353^{1}$ kc. i wykładnia zwyczaju, Acta Universitatis Wratislaviensis, Prawo CCXXXVIII, Wrocław 1994, s. 175 i nast.; A. Wolter, (w:) A.Wolter, J. Ignatowicz, K. Stefaniuk, Prawo cywilne. Zarys części ogólnej, Warszawa 2001, s. 318-320.

6 Por. E. Kucharska-Stasiak, op. cit., s. 28 oraz G. Panek, Wartość rynkowa w warunkach polskich orazw świetle europejskich i międzynarodowych standardów wyceny, „Nieruchomości” 2004, nr 4, s. 9. 


\section{Ekonomiczne aspekty nieruchomości i zarządzania przestrzenią}

$\mathrm{Z}$ punktu widzenia rynkowego, najistotniejsze jednak są cechy ekonomiczne nieruchomości. Należą do nich :

- deficytowość, czyli sytuacja, w której, przynajmniej, gdy chodzi o nieruchomości gruntowe globalnie (suma obszaru) jest stała. Nie zawsze zatem można nabyć takiego rodzaju i w takim miejscu nieruchomość, jakiej się potrzebuje,

- konieczność modernizowania, remontowania lub podziału nieruchomości aby zaspokoić potrzeby jej nabywcy (właściciela lub najemcy),

- lokalizacja - zarówno fizyczna, jak i ekonomiczna - co oznacza, że sposób użytkowania i jego zmiany są w dużym stopniu rezultatem położenia i otoczenia nieruchomości oraz jej dostępności oraz przeznaczenia,

- współzależność - miejsce położenia i sposób realizacji funkcji nieruchomości zasadniczo wpływają na jej atrakcyjność na rynku i wartość,

- wysoka kapitałochłonność - wysokie są nakłady na nabycie własności gruntu, co wpływa na wybór innej drogi do jego nabycia (u.w.), konieczność jego finansowania ze źródeł obcych (kredyt bankowy), długi okres zwrotu kapitału (amortyzacja), relatywnie długa żywotność ekonomiczna,

- mała płynność - brak łatwości i pewności zamiany nieruchomości na pieniądz za jej cenę rynkową lub do niej zbliżoną, co więcej, zależność jej wartości od sytuacji ekonomicznej (kryzysy na rynku nieruchomości). ${ }^{7}$

Wyżej wskazane cechy nieruchomości mają istotny związek z planowaniem i zagospodarowaniem przestrzennym, które przez określanie przeznaczenia konkretnej nieruchomości istotnie wpływa na jej wartość rynkową poprzez kształtowanie popytu na dany rodzaj nieruchomości, a więc na ich cenę. Ich związek z planowaniem i zagospodarowaniem przestrzennym polega na tym, że przepisy regulujące ten problem mogą wpływać na motywacje uczestników rynku nieruchomości co do kształtowania popytu na tym rynku.

Wypada przy tym zaznaczyć, iż pomimo wymiernych sukcesów gospodarczych Polski, sektor nieruchomości nadal charakteryzuje się niską wydajnością gospodarowania, co spowodowane jest w niebagatelnym stopniu tym, iż właściciele często uzyskiwali nieruchomości w wyniku procesów transformacji ustrojowej (prywatyzacja, różne procesy „uwłaszczeniowe,” komunalizacja mienia) poza mechanizmami konkurencji, które są niezbędne do zapewnienia efektywnego gospodarowania przestrzenią, a zatem nieruchomościami. Ponadto, w obliczu niewprowadzenia jeszcze podatku od wartości nieruchomości, brakuje istotnego elementu mobilizujące- 
go właścicieli, zarówno prywatnych, jak i publicznych, do poszukiwania bardziej racjonalnego i wydajnego wykorzystania najcenniejszych gruntów i budynków. ${ }^{8}$

Warto nadmienić, że inwestowanie przez gminy w tworzenie zaspokajającej potrzeby wspólnoty lokalnej przestrzeni o charakterze publicznym (parki, tereny rekreacyjne, obiekty użyteczności publicznej itp.) wymaga wzmocnienia finansów lokalnych, których struktura obecnie opiera się zbyt silnie na udziale w malejących podatkach dochodowych oraz na wyprzedaży nieruchomości komunalnych, których wartość w okresie aktualnego kryzysu gospodarczego również spada. Tymczasem podatek od nieruchomości, stanowiący istotne źródło dochodów gminy, jest (w zasadzie jako jedyny podatek) niewrażliwy na otoczenie rynkowe, co powoduje poważne wypaczenia w sferze motywacyjnej gospodarowania przestrzenią i nieruchomościami. ${ }^{9}$

Obciążanie takim samym podatkiem gruntów o różnej wartości powoduje, że właściciele nie muszą martwić się o właściwe zagospodarowanie gruntu i stać ich na to, by w celach spekulacyjnych przetrzymywać cenne grunty. W Polsce stawki podatkowe od gruntów są około 8-krotnie niższe w porównaniu do stawek od budynków (zarówno mieszkalnych, jak i gospodarczych). Jest to sprzeczne z praktyką krajów rozwiniętych gospodarczo, gdzie grunty są opodatkowane wyżej od budynków, co stymuluje do ich zagospodarowania i zniechęca do spekulacji gruntami. ${ }^{10}$ Tymczasem w Polsce największe podatki płacą np. właściciele hali, magazynów, fabryk, centrów logistycznych (ze względu wysokie stawki podatków od budynków gospodarczych), a zatem ci, którzy najbardziej przyczyniają się do wzrostu gospodarczego!

Konieczne jest podkreślenie, że prawidłowa gospodarka przestrzenią oraz nieruchomościami wymaga w pierwszej kolejności rzetelnego opracowania aktualnej ewidencji mienia podmiotów publicznych. Dopiero w oparciu o nią należy opracować strategie zarządzania nieruchomościami i określić, czy należy je sprzedawać, wynajmować, wydzierżawiać oraz na jakich zasadach należy to czynić. W odniesieniu do gmin trzeba dodać, że ważnym instrumentem w zapewnieniu prawidłowej gospodarki nieruchomościami własnymi oraz znajdującymi się na terytorium gminy jest uchwalanie miejscowych planów zagospodarowania przestrzennego, które powinny przede wszystkim dotyczyć terenów inwestycyjnych. Ustalenie przeznacze-

W.J. Brzeski, Perspektywy rozwoju sektora nieruchomości, (w:) Nieruchomości w Polsce. Pośrednictwo i zarządzanie. Kompendium, pod red. W.J. Brzeskiego [et al.], Warszawa - Kraków 2007, s. 27-28; S. Kalus, (w:) G.Bieniek, M. Gdesz, S. Kalus, G. Matusik, E. Mzyk, Ustawa o gospodarce nieruchomościami. Komentarz, Warszawa 2012, s. 869 i nast. oraz tenże, Migracja, urbanizacja a rynek nieruchomości - perspektywy rozwoju cen i wartości, Nieruchomość 2006, nr 4, s. 49. Ibidem. 
nia gruntów w dużej mierze umożliwia racjonalną gospodarkę nieruchomościami. ${ }^{11}$ W szczególności podejmowanie decyzji o zbyciu nieruchomości przed sporządzeniem studium uwarunkowań i kierunków zagospodarowania przestrzennego gminy oraz uchwaleniem miejscowego planu zagospodarowania przestrzennego stwarza niebezpieczeństwo, iż nieruchomości potrzebne do sprawnej realizacji celów publicznych będą własnością osób trzecich, a ich ponowne nabycie może być niemożliwe, kosztowne lub czasochłonne. ${ }^{12}$

Warto zaznaczyć, że gospodarowanie nieruchomościami ma ścisły związek z gospodarowaniem przestrzenią, którą tworzą nieruchomości. W praktyce obserwuje się trzy podstawowe modele gospodarowania przestrzenią, które pozwalają wyróżnić następujące rodzaje podmiotów nią gospodarujących: łupieżca, dobry gospodarz, aktualny administrator. ${ }^{13}$ Eupieżca to gospodarz, który dąży do maksymalnego wykorzystania istniejących wartości przestrzennych, a jego działania są zorientowane na chwilę bieżącą, bez uwzględniania przyszłości, zwłaszcza jeżeli miałaby ona ograniczyć korzyści doraźne. Kieruje się on własnymi interesami (politycznymi, majątkowymi) dążąc do natychmiastowej nagrody i pomijając interesy ogółu. Dobry gospodarz, inaczej aniżeli łupieżca, uwzględnia perspektywę długookresową, co powoduje, iż musi przewidywać i planować. Nie oczekuje natychmiastowej gratyfikacji, a jego działania charakteryzuje racjonalność oraz harmonizacja interesu własnego z interesem wspólnym. Pomiędzy łupieżcą a dobrym gospodarzem można umiejscowić aktualnego administratora, który nie dąży wprawdzie do uzyskania wyłącznie doraźnych korzyści, ale też nie planuje działań w perspektywie długookresowej. Jest on raczej biernym wykonawcą nałożonych na niego zadań. ${ }^{14}$

Ponadto należy przypomnieć, że gospodarowanie przestrzenią często wymaga od podmiotów publicznych określania celów tej gospodarki w oparciu o kryteria pozaekonomiczne (np. społeczne, etyczne itp.). Powoduje to, że ocena efektów gospodarowania w oparciu o ekonomiczną ocenę efektywności jest niemożliwa lub znacznie utrudniona, co jednak nie oznacza, że nie jest możliwe dokonanie oceny racjonalności przyjętych celów i założeń dotyczących ich realizacji. Ponadto należy pamiętać, że zarówno Skarb Państwa, jak i jednostki samorządu terytorialnego uczestniczą w obrocie cywilnoprawnym, co w odniesieniu do nieruchomości oznacza działanie w obrębie rynku nieruchomości, który jest charakterystycznym rynkiem kapitałowym. Tym samym również wspomniane podmioty, pomimo ich publicznego charakteru, podlegają ekonomicznym regułom funkcjonowania tego rynku i muszą je uwzględniać w procesie gospodarowania nieruchomościami.

11 Cz. Baraniecki, Gospodarowanie zasobami nieruchomości w gminie uzdrowiskowej, „Nieruchomości” 2009, nr 2, s. 15.

R. Padrak, Sprzedaż nieruchomości samorządowych i Skarbu Państwa, Wrocław 2010, s. 30-31.

A. Karwińska, Gospodarka przestrzenna. Uwarunkowania społeczno-kulturowe, Warszawa 2008, s. 49. Ibidem. 
W tym kontekście ujawnia się kolejna cecha rynku nieruchomości, którą jest potrzeba fachowej obsługi tego rynku, łącznie z jego uczestnikami. Skorzystanie z usług rzeczoznawcy majątkowego, pośrednika w obrocie nieruchomościami, lub zarządcy nieruchomości, a więc podmiotów posiadających stosowne uprawnienia lub licencje i z racji wykonywanego zawodu mające dobre rozeznanie rynku nieruchomości, z reguły wpływa na uzyskanie lepszych rezultatów w zakresie gospodarki przestrzennej oraz gospodarowania nieruchomościami. ${ }^{15}$ Warto podkreślić, że w u.g.n. ${ }^{16}$ przewidziano (art. 174 ust. 3a, art. 179 ust. 1a, art. 185 ust. 1a), iż przedstawiciele wszystkich trzech zawodów mogą świadczyć usługi z zakresu doradztwa na rynku nieruchomości także na rzecz podmiotów publicznych, przy czym zakres ten jest różny dla poszczególnych zawodów. ${ }^{17}$ Doradztwo to staje się niezbędnym narzędziem prowadzenia racjonalnego zarządzania przestrzenią na rynku wymagającym zrozumienia, rzetelnej i ciągłej analizy, którą mogą przeprowadzić profesjonaliści aktywni na tym rynku. ${ }^{18}$

Również w literaturze zagranicznej wskazuje się na zalety zarządzania nieruchomościami tzw. sektora publicznego przez specjalistów. Istotne jest to, że skuteczne zarządzanie tego typu nieruchomościami wymaga zastosowania analogicznych procesów planowania i wyznaczania strategii jak w przypadku nieruchomości prywatnych. Okazuje się, że niecierpliwość prywatnych właścicieli jest podobna do braku ciągłości działań (np. ze względu na kadencyjność) u właścicieli publicznych. W obu sektorach wyraźny jest brak zrozumienia, jak ważną rolę w osiąganiu celów i generowaniu dochodów pełni opracowanie średnio i długoterminowego programu zarzadzania, którego konsekwentna realizacja przynosi korzyści także w perspektywie krótkookresowej. ${ }^{19}$ Uwaga ta jest szczególnie aktualna w odniesieniu do gospodarki przestrzennej, której nie można prowadzić wyłącznie lub głównie w oparciu o doraźne cele i korzyści. ${ }^{20}$

Podobnie J. Szachułowicz, Gospodarowanie nieruchomościami stanowiącymi własność Skarbu Państwa oraz własność jednostki samorządu terytorialnego, (w:) Gospodarka nieruchomościami. Komentarz, pod red. J. Szachułowicza, Warszawa 2003, s. 55 oraz tenże, Własność publiczna, Warszawa 2002, s. 155-158. Zob. także S. Kalus, Pozycja prawna uczestników rynku nieruchomości, Warszawa 2009, s. 274 i nast., w której omówiono istotę i znaczenie doradztwa na rynku nieruchomości dla jego prawidłowego funkcjonowania, G. Bieniek, oraz G. Matusik aktualizacja, (w:) Ustawa o gospodarce nieruchomościami Komentarz, Warszawa 2012, s. 217 i nast. Ustawa z dnia 21 sierpnia 1997 r.o gospodarce nieruchomościami, Dz.U. 2010 r. Nr 102, poz. 651, ze zm. Zob. szerzej S. Kalus: Działalność rzeczoznawców związana z procesem finansowania inwestycji w nieruchomości, „Nieruchomości” 2010, nr 1, s. 21-22.

18 S. Kalus, Problematyka prawna doradztwa nieruchomościowego, „Nieruchomości” 2007, nr 12, s. 4-8; T. Ramian, Fundamenty analizy rynku nieruchomości, „Nieruchomości” 2007, nr 3, s. 19; W.J. Brzeski, Perspektywy rozwoju sektora nieruchomości, (w:) Nieruchomości w Polsce. Pośrednictwo i zarządzanie. Kompendium, pod red. W. Brzeskiego [et al.], Warszawa - Kraków 2007, s. 29-30.

19 A.D. White, What's in a name?, „Commercial Property Journal” 2010, nr 9-10, s. 22-23.

20 Zob. szerzej M. Habdas, Publiczna własność nieruchomości, Warszawa 2012, s. 229 i nast. 


\section{Czynniki kształtujące wartość nieruchomości}

Zjawiska występujące na rynku wpływają na wartość określonej rzeczy na różne sposoby. Przede wszystkim bowiem cena, jakiej będą żądać zbywcy na rynku za nieruchomość, uwarunkowana będzie rodzajem nieruchomości określonym wedle jej przeznaczenia oraz jej otoczenia, a to właśnie zależy od sposobu gospodarowania przestrzenią, w szczególności poprzez wykorzystanie miejscowych planów zagospodarowania przestrzennego. Trzeba też pamiętać, że występuje zależność między popytem na nieruchomości określonego rodzaju, a ich wartością. ${ }^{21}$

W związku z tym, że plany zagospodarowania przestrzennego stanowią akty prawne wydawane przez gminy, mają one charakter zmienny i mogą różnie w czasie określać przeznaczenie nieruchomości, co przekłada się na ich wartość. Mogą one zatem zmieniać tę wartość w obu kierunkach, to jest albo wpływać na wzrost wartości rynkowej określonych nieruchomości, albo też wpływać na zmniejszenie ich wartości. Nie tylko ma to poważne konsekwencje w przypadku zmiany przeznaczenia nieruchomości z rolnego na budowlane lub odwrotnie, ale także w przypadku, gdy na przykład przewidują prowadzenie dróg przez grunty do tej pory wolne od zajęcia na te cele. Zmiany te mają zwykle poważny wpływ także na cenę nieruchomości, a pośrednio na jej wartość.

Ta zależność cen nieruchomości od ich rodzajów spowodowała zresztą powstanie różnych rynków nieruchomości w zależności od ich przeznaczenia, a nawet w zależności od tego, jakim prawem do nieruchomości na rynku się rozporządza. W literaturze wyodrębnia się zatem rynek gruntów, budynków mieszkalnych, lokali, nieruchomości komercyjnych czy biurowych, rynek nieruchomości rezydencjalnych, ale także można mówić o rynku najmów czy użytkowania wieczystego albo własnościowego spółdzielczego prawa do lokali. ${ }^{22}$

W związku z powyższym należy jednak wyraźnie rozróżnić pojęcia ceny i wartości nieruchomości. Określone w aktach notarialnych ceny konkretnych nieruchomości nie zawsze są zgodne $\mathrm{z}$ wartością rynkową tych nieruchomości a jedynie mogą stanowić podstawę do określenia ich wartości. Strony konkretnej transakcji mogą bowiem kierować się różnymi motywami, wcale niekoniecznie racjonalną kalkulacją. Mogą na przykład działać w sytuacji przymusowej albo też nie mieć orientacji, jaka jest ta wartość rynkowa. W szczególności często zdarza się, iż strony rzadko uczestniczące $\mathrm{w}$ tego rodzaju obrocie mylą wartość rynkową z wartością odtworzeniową, co więcej, nawet zdarza się to w orzecznictwie sądowym, gdzie na przykład używa się pojęcia „,wartości rzeczywistej”, której w ogóle ustawa o gospo1994/95, nr 10, s. 39. 
darce nieruchomościami nie zna. ${ }^{23}$ Także dysponujący dużymi środkami inwestor, pragnący kupić nieruchomość na potrzeby bardzo pilnej inwestycji, gotów będzie z reguły zapłacić więcej niż nabywca, który tego nie zamierza. Dlatego też rolą rzeczoznawcy jest określenie wartości składnika majątkowego przy uwzględnieniu najbardziej typowych zachowań uczestników rynku i odrzuceniu tych skrajnych, skutkujących zawyżoną bądź zaniżoną ceną. ${ }^{24}$

Problem określania wartości rynkowej nieruchomości reguluje ustawa o gospodarce nieruchomościami w art. 149 i nast. u.g.n. Wprowadza ona zasady określania tej wartości nie tylko co do nieruchomości publicznych (państwowych i samorządowych), lecz stosuje się ją także do innych ze względu na podmiot własności nieruchomości.

Pojęcie tej wartości wynika $\mathrm{z}$ art. 151 u.g.n. Przewiduje on obecnie, po nowelizacji u.g.n. ustawą z 2004 r., ${ }^{25}$ iż wartość rynkową nieruchomości stanowi najbardziej prawdopodobna jej cena, możliwa do uzyskania na rynku, określona z uwzględnieniem cen transakcyjnych przy założeniu, że: a) strony umowy były od siebie niezależne, nie działały w sytuacji przymusowej oraz miały stanowczy zamiar zawarcia umowy; oraz b) upłynął czas niezbędny do wyeksponowania nieruchomości na rynku i do wynegocjowania warunków umowy. Przed wspomnianą nowelizacją przepis ten mówił o „przewidywanej cenie” nieruchomości, które to wyrażenie wydaje się mniej precyzyjne niż obecne sformułowanie ,najbardziej prawdopodobna jej cena". Zmiana ta odzwierciedla wynikające ze standardów krajowych i międzynarodowych rozróżnienie pomiędzy wartością a ceną, będącą kwotą, jaka została wynegocjowana przez strony w określonej sytuacji. ${ }^{26} \mathrm{O}$ związku wartości rynkowej z zaistniałymi na rynku transakcjami świadczy dobitnie sposób określania tej wartości, wynikający z definicji tej wartości. Art. 151 u.g.n. przewiduje bowiem konieczność uwzględnienia przy jej określaniu cen transakcyjnych, czyli w tzw. „podejściu porównawczym", a gdy cen takich brak na danym rynku, niemożliwe jest określenie wartości rynkowej nieruchomości. Trzeba wówczas uciec się do określenia wartości odtworzeniowej, co ma miejsce także w sytuacji wynikającej z obecnego użytkowania lub przeznaczenia nieruchomości. Tutaj bowiem to przeznaczenie wynikające z planu miejscowego, studium uwarunkowań oraz warunków zabudowy terenu, o których mowa w ustawie z 27 marca 2003 r. o planowaniu i zagospodarowaniu przestrzennym (Dz.U. Nr 80, poz. 717 ze zm.), oddziałuje bardzo silnie na wartość nieruchomości.

23

Por. S. Kalus, (w:) Ustawa o gospodarce nieruchomościami. Komentarz, pod red. S. Kalus, Warszawa 2012, s. 834 i nast.

Por. S. Kalus, Współdziałanie uczestników rynku nieruchomości, „Rejent” 2009, nr 2, s. 98 oraz G. Panek, op. cit., s. 10.

Na podstawie ustawy o zmianie ustawy z dnia 28.11.2003 o gospodarce nieruchomościami oraz o zmianie niektórych innych ustaw, opublikowano w Dz.U. z 21 czerwca 2004 r. Nr 141, poz. 1492

Por. G. Panek, op. cit., s. 10. 
Niewątpliwy związek pomiędzy tą ustawą a określaniem wartości rynkowej wynika także z przepisów u.g.n. i rozporządzenia Rady Ministrów z dnia 21 września 2004 r. w sprawie wyceny nieruchomości i sporządzania operatu szacunkowego (Dz.U. Nr 207, poz. 2109 ze zm.), wydane na podstawie delegacji ustawowej zawartej w art. 159 u.g.n. Rozporządzenie to określa rodzaje podejść, metod i technik wyceny nieruchomości, rozumianej jako określanie wartości nieruchomości polegające na określeniu wartości prawa własności lub innych praw do nieruchomości. Szczegółowość przepisów rozporządzenia oceniana jest w doktrynie jako nadmierna. Wiąże bowiem rzeczoznawcę majątkowego, nie pozwalając mu w zasadzie na uzasadnione odstępstwo od tych norm. Tymczasem należy podnieść, że nieruchomości są bardzo różnorodne. W zasadzie trudno znaleźć nieruchomości, nawet zlokalizowane w najbliższym sąsiedztwie, które nie różniłyby się między sobą zarówno pod względem fizycznym, mającym wpływ na ich wartość (wielkość, nasłonecznienie, funkcjonalność, dostępność, warunki geotechniczne, lokalizacyjne itp.), jak i pod względem prawnym (charakter praw do nieruchomości - własność, użytkowanie wieczyste, obciążenia rzeczowe i obligacyjne itp).

Nie ulega wątpliwości, że trafne jest stanowisko, iż podstawę ustalenia wartości nieruchomości stanowi jej stan, przez który rozumieć należy stan jej zagospodarowania, stan prawny tej nieruchomości i stan techniczno-użytkowy. Te same aspekty winny być zatem brane pod uwagę przy doborze nieruchomości porównywalnych, potrzebnych do określenia wartości rynkowej wycenianej nieruchomości. Nadto winny być brane pod uwagę cechy rynkowe tzw. nieruchomości porównywalnych, a odnoszące się do rodzajów nieruchomości, ich rozmiarów, lokalizacji, przeznaczenia w planie miejscowym, dostępności, walorów środowiskowych itp. Te wszystkie aspekty powinny być powołane w operacie szacunkowym jako kryteria zakwalifikowania nieruchomości i ich cen do porównań.

\section{Społeczny i prawny wymiar zarządzania przestrzenią}

Sprawne zarządzanie przestrzenią i gospodarowanie nieruchomościami ma wymierny wpływ na komfort życia społeczeństwa, na bezpieczeństwo i satysfakcję użytkowników przestrzeni. Źle zarządzane i niedoinwestowanie przestrzenie przestają być miejscem użytecznym, np. terenem rekreacyjnym, miejscem spotkań itp., a stają się ostoją osób bezdomnych, nadużywających alkoholu lub innych używek, dzikimi wysypiskami śmieci itp. Jest to prawidłowość, którą można łatwo zaobserwować w życiu codziennym i która została również zbadana i opisana przez przedstawicieli różnych dziedzin nauki. ${ }^{27}$ Wszystko to powoduje, że członkowie społe-

Por. B. Czarnecki, W. Siemiński, Kształtowanie bezpiecznej przestrzeni publicznej, Warszawa 2004, s. 97 i nast; W. Forysiak, Bezpieczeństwo w dużym mieście w kontekście zmian transformacyjnych. Wybrane aspekty socjologiczne, (w:) Bezpieczeństwo publiczne w przestrzeni miejskiej, pod red. W. Fehlera, Warszawa 2010, s. 172 i nast. 
czeństwa nie czują się w takich miejscach bezpiecznie i unikają ich, co tylko nasila proces ich degradacji.

W tym kontekście trzeba przypomnieć, że architektura i urbanistyka okresu socjalizmu były silnie związane $\mathrm{z}$ industrializmem i promowały głównie przemysł i produkcję, a handel i usługi zostały w dużej mierze upaństwowione. Rozwój olbrzymich ośrodków przemysłowo-mieszkalnych na przedmieściach (np. Nowa Huta, Ursus) dodatkowo przyczynił się do destrukcji przestrzeni śródmiejskiej, która po przemianach ustrojowych z 1989 roku pozostawiała wiele do życzenia z punktu widzenia użyteczności, przyjazności dla użytkowników oraz funkcjonalności. ${ }^{28}$ Zaburzenia w rozwoju miast, a co za tym idzie również terenów je otaczających, wynikały z misalokacji w użytkowaniu terenów, czyli nietrafnego zagospodarowania gruntów zurbanizowanych.

Można wyróżnić cztery misalokacje, a mianowicie: przestrzenną (rozproszenie struktury przestrzennej), funkcjonalną (nietrafne proporcje funkcji zagospodarowywanych terenów), lokalizacyjną (nieefektywna lokalizacja funkcji w terenie) oraz podmiotową (niewłaściwe rozlokowanie użytkowników istniejących zasobów nieruchomości). Powodują one konieczność przebudowy struktury przestrzennej wielu miast, w tym także rewitalizacji przestrzeni, w celu zakończenia niewydajnego sposobu zagospodarowania oraz wykorzystywania gruntów i budynków. ${ }^{29}$

Rozważając jakość, bezpieczeństwo i przyjazność, w szczególności przestrzeni o charakterze publicznym, J. Fehler wskazuje, że dla atrakcyjności i wysokiego stopnia akceptacji przestrzeni decydujące są następujące czynniki:

- zachowanie ładu przestrzennego,

- respektowanie zasady trwałego i zrównoważonego rozwoju,

- dostępność,

- wysoki poziom ochrony przed zagrożeniami,

- zdolność zaspokajania potrzeb użytkowników,

- dobre zarządzanie. ${ }^{30}$

G. Makowski, Świątynia konsumpcji. Geneza i społeczne znaczenie centrum handlowego, Warszawa 2004, s. $55-56$.

29 W.J. Brzeski, Migracja..., s. 47-48. Szerzej o przyczynach zaburzeń rozwoju polskich miast zob. M. Kopeć, Rewitalizacja miejskich obszarów zdegradowanych, Warszawa 2010, s. 67 i nast. Zob. także J. Gehl, L. Gemzoe, New City Space, Copenhagen 2006, s. 14, gdzie autorzy wskazują na cztery rodzaje miast, w zależności od wykorzystania ich przestrzeni. Miasto tradycyjne (the traditional city) posiada równowagę pomiędzy funkcjami społecznymi, a ruchem ulicznym. W mieście w stanie inwazji (the invaded city) ruch uliczny pochłania całą wolną przestrzeń w centrum miasta. Miasto porzucone (the abandoned city) jest opustoszałe, brakuje tzw. życia między budynkami. Miasto odzyskane (the reconquered city) charakteryzuje się widocznymi działaniami władz, które przywracają równowagę pomiędzy różnymi funkcjami nieruchomości w obrębie miasta, uwzględniając zapotrzebowanie na dobrej jakości przestrzeń publiczną. red. W. Fehlera, Warszawa 2010, s. 18. 
Wymienione elementy są silnie związane z zagadnieniami prawnymi, takimi jak: zagospodarowanie przestrzenne, ochrona środowiska czy też zarządzanie nieruchomościami, a zatem nie są to czynniki, które można lub należy rozważać tylko na płaszczyźnie socjologii czy urbanistyki. Przeciwnie, okazuje się, że zagrożenia dla przestrzeni wynikają m.in. ze: słabości systemu planowania przestrzennego, występowania barier w zakresie pozyskiwaniai przeznaczenia terenów na urządzenia publiczne (ulice, parkingi), legalnej i nielegalnej prywatyzacji przestrzeni (także poprzez umieszczanie szyldów i reklam), które powinny pozostawać publiczne. Dodatkowo wskazuje się na:

- nieuzasadnione przyjmowanie, iż wolny rynek, bez interwencji władz publicznych, jest w stanie zapewnić zrównoważony rozwój,

- preferowanie doraźnych korzyści ekonomicznych nieuwzględniających średnio- i długookresowych skutków podjętych decyzji, a także wartości niewymiernych i ponadczasowych, generowanych przez przestrzeń publiczną,

- brak efektywnego nadzoru urbanistycznego, naruszanie zasady dobrego sąsiedztwa przy projektowaniu i budowaniu nowych obiektów, brak przemyślenia i zapewnienia sprawiedliwego dostępu do przestrzeni publicznych, minimalizującego konflikty związane z jej użytkowaniem. ${ }^{31}$

Warto w tym miejscu podkreślić, że możliwe jest takie projektowanie przestrzeni, które minimalizuje zagrożenie przestępczością. ${ }^{32} \mathrm{~W}$ Wielkiej Brytanii funkcjonują specjalni doradcy (Crime Prevention Design Advisors), wykorzystywani zarówno przez władze lokalne, jak i policję, którzy specjalizują się w analizowaniu projektów zagospodarowywania przestrzeni pod kątem jej przyszłego bezpieczeństwa. ${ }^{33}$ Zagadnienie to jest bardzo istotne także w kontekście tego, iż samodzielne korzystanie przez dzieci z przestrzeni otwartych, takich jak parki i place zabaw, jest coraz rzadsze. W konsekwencji obserwuje się zjawisko zamykania dzieci w domach wtedy, gdy rodzice nie mogą osobiście (najczęściej ze względu na pracę) lub poprzez opłacaną pomoc (najczęściej ze względów ekonomicznych) nadzorować zabaw dzieci w przestrzeni publicznej. ${ }^{34}$

Istotne jest także udzielenie odpowiedzi na pytanie dotyczące zakresu, w którym należy dopuścić zastępowanie tradycyjnie pojmowanej przestrzeni publicznej lub publicznego forum przestrzenią prywatną, którą tworzą najczęściej potężni inwestorzy. Ich siła ekonomiczna powoduje, że większość ich życzeń dotyczących

Ibidem, s. 18-22.

B. Czarnecki, W. Siemiński, Kształtowanie..., s. 108 i nast., gdzie omówiono przestrzenno-organizacyjne uwarunkowania bezpieczeństwa w zakresie przestępczości.

R. Hampshire, Designing-out crime, „RICS Commercial Property Journal” 2011, nr 5-6, s. 20-21.

Zob. szerzej C. Katz, Power, Space and Terror: Social Reproduction and the Public Environment, (w:) The Politics of Public Space, pod red. S. Low, N. Smith, New York - London 2006, s. 105 i nast., w szczególności s. 114115. 
zagospodarowywanego terenu jest spełniana, włącznie $\mathrm{z}$ dokonywaniem zmian miejscowych planów zagospodarowania przestrzennego lub wydawaniem decyzji o warunkach zabudowy i zagospodarowania terenu, ${ }^{35}$ których zgodność z zasadą dobrego sąsiedztwa ${ }^{36}$ oraz zrównoważonego rozwoju jest dyskusyjna. Najczęstszym zjawiskiem jest zastępowanie terenów rekreacyjno-sportowych oraz parków, atrakcyjnie zlokalizowanych w obrębie miasta, centrami handlowymi, pozbawiając mieszkańców dostępu do terenów zielonych, rekreacyjnych (publicznie dostępne boiska do gry w piłkę nożną lub koszykówkę, parki skatowe, place zabaw, pływalnie kryte lub kąpieliska otwarte), uzupełniających funkcje mieszkaniowe. ${ }^{37}$ Tego typu procesy mają duży wpływ na wartość nieruchomości. Być może wartość nieruchomości na skutek jej zabudowania centrum handlowym wzrasta, lecz wartość nieruchomości mieszkalnych znajdujących się w jej pobliżu zazwyczaj spada ze względu na uciążliwość takiego sąsiedztwa, a także pozbawienie mieszkańców dostępu do terenów o funkcjach uzupełniających funkcje nieruchomości mieszkalnych.

Trzeba również pamiętać o tym, iż kształtowanie przestrzeni następuje nie tylko przy wykorzystaniu typowych instytucji ustawy o planowaniu i zagospodarowaniu przestrzennym. ${ }^{38}$ Unikalną możliwość kształtowania przestrzeni daje Skarbowi Państwa i jednostkom samorządu terytorialnego użytkowanie wieczyste, a to ze względu na celowy charakter prawa i uprawnienie wynikające z art. 240 kc. ${ }^{39}$ Warto przy tym wspomnieć, że użytkowanie wieczyste jest wprawdzie prawem o szerokiej treści normatywnej, lecz jest to prawo na rzeczy cudzej, a na dodatek prawo o charakterze odpłatnym. Jednak brak regularnej aktualizacji opłaty rocznej za użytkowanie wieczyste spowodował, że wartość rynkowa tego prawa w istocie była taka sama lub bliska wartości prawa własności nieruchomości.

Wynikało to z faktu, iż obciążenie opłatą roczną było nieznaczne, a szeroka treść normatywna użytkowania wieczystego oraz jego długi okres trwania powodowały, że opłata ta nie wpływała w większym zakresie na opłacalność inwestycji. Tym samym na rynku doszło do swoistego paradoksu, gdyż prawo silniejsze (własność) i prawo słabsze (tj. użytkowanie wieczyste będące prawem: na rzeczy cudzej, terminowym, odpłatnym) miały w istocie identyczną wartość rynkową. Niejednokrotnie zdarzało się nawet, że za użytkowanie wieczyste inwestorzy płacili więcej

Zob. ustawę z dnia 27 marca 2003 r. o planowaniu i zagospodarowaniu przestrzennym (u.p.z.p.), Dz.U. Nr 80, poz. 717 z późn. zm., art. 14 i nast. oraz art. 59 i nast.

Zob. rozporządzenie Ministra Infrastruktury z dnia 26 sierpnia 2003 r. w sprawie sposobu ustalania wymagań dotyczących nowej zabudowy i zagospodarowania terenu w przypadku braku miejscowego planu zagospodarowania przestrzennego, Dz.U. Nr 164, poz. 1588 z późn. zm., § 3. i przestrzeń publiczna, pod red. T. Markowskiego, Warszawa 2001, s. 65-67. Zob. szerzej M. Habdas, Publiczna..., s. 365 i nast.

39 M. Habdas, Użytkowanie wieczyste i jego znaczenie na polskim rynku nieruchomości, „Prawo Spółek” 1999, nr 4, s. 55; E. Kucharska-Stasiak, Głos w dyskusji, (w:) Reforma prawa użytkowania wieczystego - prawo zabudowy, Warszawa - Kraków 2009, s. 52. 
aniżeli za prawo własności (czyli w przetargu cena przekraczała ponad czterokrotnie wartość rynkową własności nieruchomości - opłata roczna zazwyczaj wynosi $25 \%$ tej ceny), gdyż nienaturalnie zawyżony koszt opłaty pierwszej inwestorzy przerzucali na przyszłych nabywców np. wyodrębnianych nieruchomości lokalowych. ${ }^{40}$ Dobrze więc, że ustawodawca zdecydował się wprowadzić aktualizację opłat rocznych z tytułu użytkowania wieczystego jako obowiązkowy element planu wykorzystania zasobów nieruchomości określonych w u.g.n. Stało się to jednak dopiero w 2007 r., a więc kilkanaście lat po powstaniu wolnego rynku nieruchomości. Aktywna i sensowna polityka dotycząca aktualizacji opłat rocznych może w dużym stopniu ukształtować to, w jakich sektorach rynku nieruchomości i dla jakiego rodzaju inwestycji prawo to będzie przydatne.

Warto nadmienić, że w przeszłości dokonywanie aktualizacji opłat z tytułu użytkowania wieczystego było nieregularne, a często przez wiele lat w ogóle nie było przeprowadzane. Tymczasem sytuacja na rynku nieruchomości podlegała od 1990 r. dynamicznym zmianom, które powodowały istotne zmiany w wartości nieruchomości. ${ }^{41}$ Brak aktualizacji opłat z tytułu użytkowania wieczystego najczęściej powodował zaniżenie wpływów do budżetów Skarbu Państwa i jednostek samorządu terytorialnego, co negatywnie wpływało na możliwość realizacji przez te podmioty nałożonych na nie zadań. ${ }^{42}$ Nie sposób także pominąć niekorzystnego wpływu takiej sytuacji na użytkowników wieczystych, którzy przyzwyczaili się do „nierynkowych" opłat rocznych z tytułu użytkowania wieczystego i czuli się wręcz oszukani (do czego przyczyniają się również relacje w mediach), ${ }^{43}$ gdy po wielu latach (często nawet kilkunastu) właściciele nieruchomości zaczęli wykonywać swoje uprawnienia. ${ }^{44}$

Tego typu zjawiska powodują, iż gospodarowanie nieruchomościami jest nieefektywne, gdyż nie generują one dochodów niezbędnych do utrzymania ich

40 S. Kalus, Prawo użytkowania wieczystego w Polsce - jego ewolucja i stan obecny, (w:) Reforma prawa użytkowania wieczystego - prawo zabudowy, Warszawa - Kraków 2009, s. 29; J. Lipiński, Głos w dyskusji, (w:) Reforma prawa użytkowania wieczystego - prawo zabudowy, Warszawa - Kraków 2009, s. 53-54.

41 Zob. wyrok Sądu Apelacyjnego w Warszawie z 4 marca 2004 (VI ACa 667/03), „Wokanda” 2005, nr 5, s. 40, w którym wskazano, iż w sprawie o ustalenie wysokości aktualizowanej opłaty rocznej z tytułu użytkowania wieczystego wyboru właściwego podejścia, metody oraz techniki szacowania nieruchomości dokonuje rzeczoznawca, a nie wola którejkolwiek ze stron użytkowania wieczystego. Wybór ten nie może być dowolny, lecz racjonalny, uzasadniony zasadami szacowania wartości nieruchomości określonymi przepisami ustawy o gospodarce nieruchomościami i aktem wykonawczym do tej ustawy. S. Kalus, Prawo..., s. 30.

Zob. np. M. Wielgo, Podwyżka za wieczyste użytkowanie bez ograniczeń, „Gazeta Wyborcza” z 23 listopada 2010; tenże, Gminny haracz zachęca do grodzenia osiedli, „Gazeta Wyborcza” z 16 stycznia 2011 oraz: W pułapce opłat za użytkowanie wieczyste gruntu, Gazeta Wyborcza z 4 stycznia 2011.

44 Zob. wyrok WSA w Białymstoku z 13 listopada 2007 (II SA/Bk 591/07 ), Lex nr 340369, w którym sąd wyjaśnił, iż opłaty z tytułu użytkowania wieczystego mają charakter cywilnoprawny, natomiast wypowiedzenie dotychczasowej stawki opłaty rocznej z tytułu użytkowania wieczystego następuje w ramach realizacji uprawnień cywilnoprawnych właściciela nieruchomości obciążonej użytkowaniem wieczystym, a nie w następstwie sprawowania jurysdykcji administracyjnej. 
chociażby we właściwym stanie technicznym, a to z kolei powoduje trudności w zarządzaniu przestrzenią. Należy przy tym ponownie podkreślić, że nieruchomości należą do dóbr wysoce kapitałochłonnych i niski poziom generowanych przez nie dochodów redukuje skalę nakładów inwestycyjnych właściciela. Prowadzi to do systematycznego powiększania się tzw. „luki remontowej”, która skutkuje w przyszłości albo dewastacją mienia, albo koniecznością ponoszenia dramatycznie zwiększonych nakładów na jego ratowanie. Zaniechanie dochodzenia przez właścicieli roszczeń z tytułu należnych opłat, czynszów itp. oraz prowadzenia ich systematycznej aktualizacji powoduje także, iż gospodarstwa domowe angażują dostępne środki finansowe na zakup towarów mniej lub bardziej luksusowych (samochody, sprzęt komputerowy, RTV, AGD) kosztem ponoszenia wydatków związanych z dbałością o wykorzystywaną nieruchomość. ${ }^{45}$

\section{Podsumowanie}

Odpowiedzialne zarządzanie przestrzenią poprzez gospodarkę przestrzenną i gospodarkę nieruchomościami daje wymierne korzyści. Można do nich zaliczyć wzrost wartości kapitałowej lub czynszowej nieruchomości, polepszenie jakości życia społeczeństwa, obniżenie kosztów utrzymania przestrzeni poprzez motywację jej użytkowników do jej właściwego wykorzystania, a nawet obniżenie poziomu przestępczości. Należy pamiętać, że gospodarka przestrzenna jest silnie związana z rynkiem nieruchomości, a relacje pomiędzy rynkiem a gospodarką przestrzenną mają charakter sprzężenia zwrotnego, a zatem oddziaływanie następuje w obu kierunkach.

Wartość rynkowa nieruchomości w dużej mierze zależy od możliwości jej wykorzystania do określonych celów, które ustala się, uwzględniając przepisy o planowaniu i zagospodarowaniu przestrzennym, w tym akty prawa miejscowego. Z kolei znaczna wartość nieruchomości i atrakcyjne wykorzystanie nieruchomości pozytywnie wpływa na przestrzeń, która ją otacza, mobilizując do jej dalszego rozwoju i optymalnego wykorzystania.

Zarządzanie przestrzenią jest jednak procesem ciągłym i skomplikowanym, gdyż zgodnie z powyższymi uwagami wymaga uwzględnienia czynników społecznych, ekonomicznych, prawnych i finansowych. $\mathrm{Z}$ tego powodu gospodarka przestrzenna nie może mieć charakteru doraźnego, lecz musi opierać się na jasno wyznaczonych celach, w tym średnio i długookresowych. Gospodarka przestrzenna winna być prowadzona nie tylko w oparciu o typowe instrumenty planistyczne o charakterze administracyjnoprawnym, ale także z pełnym wykorzystaniem możliwości, 
jakie dają instrumenty prawa cywilnego. Dopiero kompleksowe stosowanie przez jednostki administracji publicznej, w szczególności samorządowej, instrumentów cywilistycznych i administracyjnoprawnych, z uwzględnieniem ich kontekstu rynkowego, pozwoli na efektywne zagospodarowanie przestrzeni. 
Ustawa o planowaniu i zagospodarowaniu przestrzennym jako instrument...

THE ACT ON SPATIAL PLANNING AND MANAGEMENT AND ITS INFLENCE ON THE MARKET VALUE OF IMMOVABLES

Key words: spatial planning, market value of immovables, real estate market.

The paper considers three basic notions, namely: immovables and their legal economic features, the real estate market and its characteristics, and finally spatial planning as a means of influencing the market value of immovables. Its aim is to consider how spatial planning instruments influence the market value of immovables and how economic features of immovables and of the real estate market are to be considered when dealing with spatial planning issues.

It is shown, that proper spatial management brings about many benefits, including the increase in market or rental value of real estate, the improvement of citizens' quality of life, the decrease in costs of maintaining real estate by motivating their users to keep them in good condition. It is emphasized, that spatial planning and management must be viewed not only from a legal perspective but also in the context of economic factors which are relevant to the real estate market.

The market value of an immovable to a large extent depends on the possibility of developing it and this in turn is regulated by local development plans. Simultaneously, well developed spaces cause increases in market values and positively influence the neighboring areas, stimulating growth and highest and best use of available space. Spatial planning is not, however, a short term activity, as its effects must be planned and assessed also, or perhaps predominantly, in long term analyses. It is also important to note, that management of spaces may be carried out not only with the use of administrative instruments, but also through the active application of possibilities which arise from private law. 